\title{
SOSIALISASI PENTINGNYA PENDIDIKAN LEBIH TINGGI DI DESA SUNGAI MALI KECAMATAN KETUNGAU HILIR
}

\author{
Munawar Thoharudin ${ }^{1}$, Avelius Dominggus Sore ${ }^{2}$, Yulia Suriyanti ${ }^{3}$ \\ Pendidikan Ekonomi, STKIP Persada Khatulistiwa Sintang, Indonesia ${ }^{1}$ \\ Pendidikan Ekonomi, STKIP Persada Khatulistiwa Sintang, Indonesia ${ }^{2}$ \\ Pendidikan Ekonomi, STKIP Persada Khatulistiwa Sintang, Indonesia ${ }^{3}$ \\ Email: munnawar.thoha99@gmail.com.suryantiyuli@yahoo.co.id, \\ aveliusdominggus12@gmail.com
}

\begin{abstract}
Tujuan dari kegiatan ini adalah (1) meningkatkan motivasi siswa SMP Negeri Sungai Mali untuk melanjutkan pendidikan ke jenjang yang lebih tinggi, (2) menumbuhkan kesadaran pihak keluarga dalam memberikan dukungan terhadap anaknya agar mau melanjutkan pendidikan setelah lulus dari SMP Negeri Sungai Mali, (2) siswa SMP Negeri Sungai Mali memiliki pengetahuan serta gambaran tentang pendidikan tingkat SMA dan perguruan tinggi. Pelaksanaan kegiatan melalui metode ceramah, diskusi dan bermain peran serta evaluasi. Kesimpulan dari kegiatan ini adalah: (1) meningkatnya motivasi para siswa SMP negeri Sungai Mali untuk melanjutkan pendidikan ke jenjang lebih tinggi, (2) tumbuhnya kesadaran dari orangtua siswa untuk memberi dukungan dan kesempatan bagi anaknya dalam melanjutkan pendidikan ke jenjang yang lebih tinggi, (3) siswa memperoleh pengetahuan dan gambaran tentang pendidikan tingkat SMA dan perguruan tinggi
\end{abstract}

Keywords: Sosialisasi, Pendidikan, Pendidikan Tinggi

\begin{abstract}
Abstrak(Times New Roman 11): The purpose of this activity is (1) increasing the motivation of Sungai Mali Junior High School students to continue their education to a higher level, (2) fostering awareness of the family in providing support for their children to want to continue their education after graduating from Sungai Mali Junior High School, (2) Sungai Mali Junior High School students have the knowledge and description of university and college level education. Implementation of activities through lecture, discussion and role playing methods and evaluation. The conclusions of this activity are: (1) increased motivation of Sungai Mali Junior High School students to continue their education to a higher level, (2) growing awareness of parents to provide support and opportunities for their children to continue their education to a higher level, (3) students gain knowledge and description about high school and university
\end{abstract}

Kata Kunci: Socialization, Education, University 
PENDAHULUAN

Pendidikan mempunyai peranan yang penting dalam kehidupan suatu bangsa, maju tidaknya suatu bangsa dipengaruhi oleh kualitas pendidikan bangsa itu sendiri. Oleh karena itu pemerintah berupaya meningkatkan kualitas sumber daya manusia dalam dunia pendidikan. Pendidikan sebagaimana tercantum dalam Undang-Undang No 20 tahun 2003 bab II pasal 3 tentang Sistem Pendidikan Nasional menegaskan bahwa : "Pendidikan nasional berfungsi mengembangkan kemampuan dan membentuk watak serta peradaban bangsa yang bermartabat dalam rangka mencerdaskan kehidupan bangsa, bertujuan untuk berkembangnya potensi peserta didik agar menjadi manusia yang beriman dan bertakwa kepada Tuhan Yang Maha Esa, berakhlak mulia, sehat, berilmu, cakap, kreatif, mandiri, dan menjadi warga Negara yang demokratis serta bertanggung jawab"

Pendidikan merupakan penentu keberhasilan pembangunan suatu bangsa. Pendidikan menjadi modal budaya sehingga mampu meningkatkan kesejahteraan dan kualitas hidup. Di era global sekarang ini, berbagai bangsa di dunia telah mengembangkan knowledge-based economy (KBE), yang mensyaratkan dukungan manusia berkualitas. Karena itu, pendidikan mutlak diperlukan guna menopang pengembangan ekonomi berbasis pengetahuan - education for the knowledge economy (EKE) (Suryana, 2017:1)

Pendidikan merupakan suatu usaha manusia untuk membina kepribadian agar sesuai dengan norma norma atau aturan dalam masyarakat. Di Indonesia setiap anak yang sudah memasuki usia sekolah yakni antara 7-15 tahun ditekankan wajib mendapatkan pendidikan mulai dari SD sampai SMP yang merupakan syarat terendah untuk dapat memasuki lapangan kerja formal. Namun seseorang yang sudah menamatkan pendidikan di SMA/ sederajat haruslah melanjutkan pendidikan ke Perguruan Tinggi. Hal ini tentu dimaksudkan agar setiap orang dapat memperoleh pendidikan dan keterampilan yang cukup dalam menghadapi masa kehidupannya dan memiliki daya saing yang memadai.

Setiap orangtua didalam masyarakat dapat menjadi pendidik, sebab pendidik merupakan suatu perbuatan sosial yang mendasar untuk pertumbuhan atau perkembangan anak didik agar menjadi manusia yang mampu berpikir dewasa dan bijak. Keluarga dalam hal ini orangtua sebagai lingkungan pertama, dan utama dimana anak berinteraksi, sebagai Lembaga Pendidikan tertua, artinya ditempat inilah proses pendidikan dimulai dan ditempat inilah pendidikan paling banyak diterima oleh anak. Menurut Hasbullah (2015) 
dalam tulisannya tentang dasar dasar ilmu pendidikan, bahwa keluarga sebagai lembaga pendidikan nmemiliki beberapa fungsi yakni fungsi dalam perkembangan kepribadian anak,dan mendidik anak dirumah, fungsi keluarga atau orangtua dalam mendukung pendidikan disekolah

Untuk dapat menjalankan fungsi tersebut secara maksimal, orangtua harus memiliki kualitas yamg memadai, sehingga anak-anak dapat berkembang sesuai dengan harapan, artinya orangtua harus memahami hakikat dan peran mereka sebagai orangtua dalam membesarkan anak, mendaptkan pengetashuan ttg pola pengasuhan yang tepat, pengetahuan tentang pendidikan yang dijalani anak, ilmu tentang perkembangan anak. Hal dimaksud agar orangtua tidak salah dalam menerapkan pola pendidikan terhadap anak.

Kesalahan dalam interaksi keluarga yang dikarenakan kurang optimal anggota keluarga dalam melaksanakan peran dan fungsinya masing masing dapat menimbulkan berbagai permasalahan dalam keluarga. Pandangan konstruksi perkembangan percaya bahwa, ketika individu itu tumbuh mereka mendapatkan model berhubungan dengan oranglain.

Sejatinya pendidikan dimulai dari keluarga, karena tidak ada orang yang tidak dilahirkan dalam keluarga. Jauh sebelum ada lembaga pendidikan yang disebut sekolah, Keluarga telah ada sebagai lembaga yang memainkan peran penting dalam pendidikan yakni sebagai peletak dasar. Dalam dan dari keluarga orang mempelajari banyak hal, dimulai dari bagaimana berinteraksi dengan oranglain, menyatakan keinginan dan perasaan, menyampaikan pendapat, bertuturkata, bersikap, berperilaku hingga bagaimana mengatur nilai nilai tertentu sebagai prinsip dalam hidup. Intinya keluarga adalah basis pendidikan setiap orang.

Secara praktis, pendidikan dalam keluarga tidak mempunyai suasana seperti pendidikan disekolah. Pendidikan dalam keluarga memiliki ciri khas tersendiri. Hal ini dimungkinkan, karena pendidikan dalam keluarga bukanlah pendidikan yang diorganisasikan tetapi pendidikan yang organik yang didasrkan atas spontanitas, intuisi, kebiasaan dan improvisasi. Fungsi sosialisasi dan pendidikan adalah untuk mendidik anak mulai dari awal sampai pertumbuhan anak hingga terbentuk personality-nya. Menurut Narwoko dan Bagus (sudarwati dan Raditya, 2014:5). Keluarga mempunyai peranan penting dalam fungsi ini karena keluargalah yang membentuk dan mengarahkan karakter setiap individu yang nantinya juga akan bermasyarakat

Menurut sudarwati dan Raditya, (2014:3) Tingkat 
pendidikan menjadi konsekuensi logis dalam perkembangan di era industrialisasi.

Perkembangan industrialisasi menuntut tenaga kerja professional dalam bidang-bidang khusus yang terklasifikasikan.

Dengan demikian, tujuan dari kegiatan ini adalah (1) meningkatkan motivasi siswa SMP Negeri Sungai Mali untuk melanjutkan pendidikan ke jenjang yang lebih tinggi, (2) menumbuhkan kesadaran pihak keluarga dalam memberikan dukungan terhadap anaknya agar mau melanjutkan pendidikan setelah lulus dari SMP Negeri Sungai Mali, (2) siswa SMP Negeri Sungai Mali memiliki pengetahuan serta gambaran tentang pendidikan tingkat SMA dan perguruan tinggi.

\section{METODE PELAKSANAAN}

Kegiatan sosialisasi pentingnya pendidikan lebih tinggi di Sekolah Menengah Pertama (SMP) Negeri Sungai Mali sebagai peserta sosialisasi, sesuai dengan persiapan waktu dan tempat serta lingkungan yang mendukung, dalam pelaksanaannya juga menggunakan beberapa metode sebagai berikut:

a. Ceramah bervariasi

Metode ini dipilih untuk menyampaikan konsep-konsep yang penting untuk dimengerti dan dikuasai oleh peserta sosialisasi. Penggunaan metode ini dengan pertimbangan bahwa dengan metode ceramah yang dikombinasikan dengan contoh-contoh relevan terkait manfaat menempuh pendidikan yang lebih tinggi. Materi sosialisasi yang akan disampaikan meliputi: jenis jenjang pendidikan formal, apa yang dimaksud pendidikan tinggi, manfaat penting yang dapat diperoleh setelah menempuh pendidikan tinggi yang disertai contoh-contoh konkret dan riil kesuksesan setelah menempuh pendidikan tinggi.

b. Diskusi

Metode diskusi dilaksanakan dalam bentuk tanya jawab peserta yaitu siswa SMP Negeri Sungai Mali dan orangtua dengan para pemateri, mengutarakan pendapat, dan berdialog. Dalam bagian ini, peserta PKM yaitu siswa SMP Negeri Sungai Mali dan orangtua sangat aktif melakukan diskusi dan tanya jawab.

c. Bermain Peran

Metode ini dipilih untuk memperlihatkan manfaat dari menempuh pendidikan tinggi melalui drama mini yang dipraktekkan oleh siswa SMP Negeri Sungai Mali yang mana skenario telah disiapkan oleh anggota pengabdian. Pada tahap ini siswa tampak menikmati dan fokus pada cerita. Diakhir drama juga dibacakan kesimpulan tentang cerita yang telah ditampilkan.

d. Evaluasi

Kegiatan evaluasi dilakukan secara langsung oleh pelaksana. Evaluasi pelaksanaan $\mathrm{PkM}$ ini berupa tes dan angket yang disebarkan kepada seluruh peserta. Proses evaluasi dilaksanakan untuk 
mengetahui kekurangan dan kendala dalam pelaksanaan kegiatan.

Pada tahap ini, peserta diminta untuk mengisi angket tentang kepuasan dari kegiatan sosialisasi yang telah dilaksanakan. Angket berisi pernyataan untuk mengukur pengetahuan dan pemahaman siswa terhadap materi sosialisasi yang telah diberikan serta mengukur peingkatan motivasi untuk melanjutkan pendidikan ke jenjang SMA dan perguruan tinggi. Angket lainnya diberikan kepada orangtua siswa untuk mengukur peningkatan kesediaan dalam memberikan dukungan baik berupa motivasi maupun materi agar anaknya mau melanjutkan pendidikan ke jenjang lebih tinggi

\section{HASIL DAN PEMBAHASAN}

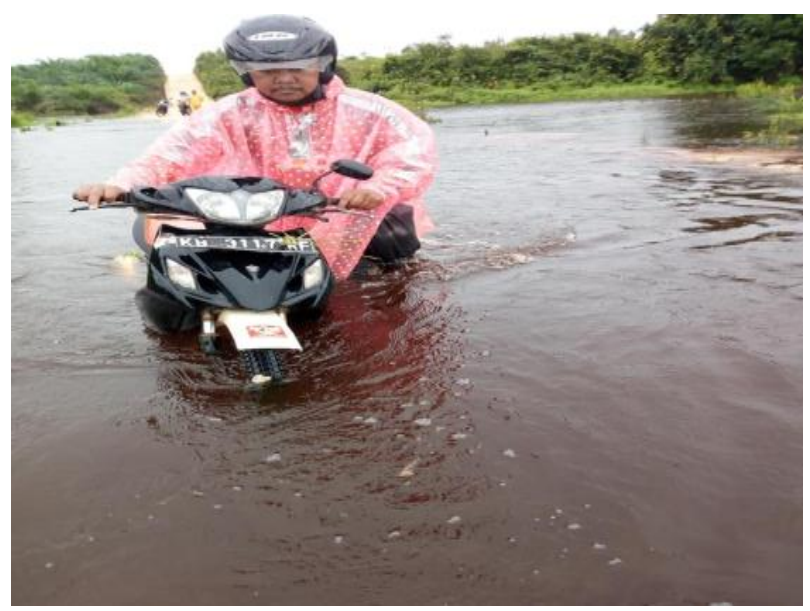

Gambar 1

Kondisi Jalan Menuju Desa Sungai Mali yang Tergenang Banjir pada Musim Hujan

Kondisi yang semakin camat Ketungau Hilir terkait memprihatinkan dipaparkan oleh rendahnya minat melanjutkan kepala desa dan juga diiyakan oleh pendidikan masyarakat di daerah

\begin{abstract}
di Kecamatan Ketungau Hilir, desa Sungai Mali. Sekolah ini merupakan satu-satunya SMP Negeri di Kecamatan tersebut. Jumlah siswa mencapai enam puluhan orang dengan daerah asal siswa mayoritas dari sekitar Ketungau Hilir. Meskipun sekolah ini berada di kecamatan, akses masih sangat sulit. Jalan rusak dan pada musim hujan banjir hingga menutup semua akses transportasi darat. Pada gambar 1 . Menunjukkan akses menuju sekolah yang hampir tidak dapat dilalui dikarenakan banjir.

Sekolah Menengah Pertama

Sekolah Menengah Pertama (SMP) Negeri Sungai Mali terletak
\end{abstract}

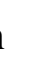
. 
tersebut. Data menunjukkan bahwa $10 \%$ masyarakat tidak mengenyam bangku sekolah formal, 50\% masyarakat hanya lulus Sekolah Dasar (SD), 30\% lulus Sekolah Menengah Pertama (SMP) dan 10\% lulus Sekolah Menengah Atas (SMA) dan perguruan tinggi. Berdasarkan kondisi tersebut maka tim PKM melaksanakan pengabdian kepada masyarakat berupa sosialisasi tentang pentingnya pendidikan tinggi.

\section{Pelaksanaan Kegiatan}

Pelaksanaan PKM ini diikuti oleh seluruh siswa SMP Negeri Sungai Mali dan diikuti pula oleh orangtua siswa beserta semua guru yang mengajar di sekolah tersebut. Adapun harapan menghadirkan orangtua dalam pelaksanaan sosialisasi adalah agar orangtua dapat memberikan dukungan kepada anaknya dalam melanjutkan pendidikan ke jenjang yang lebih tinggi setelah memperoleh gambaran tentang manfaat dari menempuh pendidikan tinggi.

Pemaparan materi disajikan dalam bentuk ceramah oleh para anggota pengabdian. Pada sesi pertama dimulai dengan pembukaan dan sambutan oleh kepala Sekolah SMP Negeri sungai mali serta Kepala desa Sungai Mali. Berikutnya kemudian dilanjutkan dengan penyampaian materi sosialisasi tentang pentingnya melanjutkan pendidikan ke jenjang yang lebih tinggi. Melanjutkan pendidikan ke jenjang yang lebih tinggi bukan hanya bertujuan untuk meningkatkan strata pendidikan yang didapat, namun dengan melanjutkan pendidikan juga mampu meningkatkan keterampilan serta pengetahuan yang dimiliki agar berkembang dengan lebih baik lagi.

Dalam hal ini, pemateri memberikan pemaparan tentang manfaat dari menempuh pendidikan tinggi. Adapun yang dimaksud pendidikan tinggi disini adalah jenjang pendidikan Sekolah Menengah Atas (SMA) dan perguruan tinggi. Penyampaian materi oleh Bapak Munawar Thoharudin, M.Pd ditujukan kepada siswa dan siswi SMP Negeri Sungai Mali secara khusus dikarenakan $80 \%$ siswa yang lulus dari SMP tersebut tidak melanjutkan sekolah ke jenjang yang lebih tinggi. Penguatan materi pada pengabdian ini diberikan kepada orang tua siswa. Keluarga merupakan media pembelajaran dalam kehidupan seharihari seseorang akan selalu berinteraksi dengan lingkungan Faktor lingkungan keluarga yang mempengaruhi minat peserta didik melanjutkan pendidikan tinggi adalah pendidikan orang tua, ekonomi orang tua dan saudara (Khadijah dkk, 2017:181)

Diharapkan setelah mengikuti kegiatan pengabdian siswa memiliki motivasi untuk melanjutkan sekolah. Senada yang diungkapkan Suryana (2017:4) Meningkatnya 
partisipasi pendidikan menengah tersebut akan menimbulkan tekanan baik pada penyediaan kesempatan belajar di pendidikan tinggi maupun pada upaya peningkatan mutu dan relevansi pendidikan menengah agar para lulusannya dapat memperoleh pekerjaan yang layak.

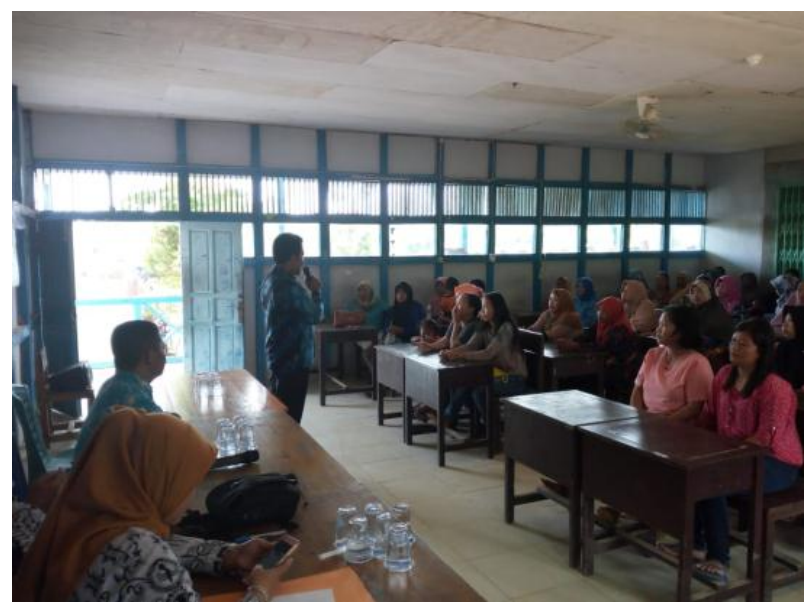

Gambar 2

Menunjukkan penyaji memberikan materi kepada orang tua siswa

Sesi selanjutnya adalah tanya jawab. Anggota pengabdian memberikan kesempatan bagi siswa untuk mengajukan pertanyaan terkait materi pengabdian. Pada sesi ini penyaji juga memberikan informasi tentang Sekolah Menengah Atas (SMA) yang ada di kota Sintang serta perguruan tinggi yang dapat dipilih siswa kelak untuk melanjutkan pendidikan.

Sesi ketiga dilanjutkan dengan kegiatan bermain peran. Skenario yang telah disiapkan oleh anggota pengabdian diberikan kepada beberapa siswa untuk dimainkan. Adapun isi cerita dari skenario tersebut adalah bagaimana kemudahan dari seseorang yang memiliki pendidikan tinggi dalam memperoleh pekerjaan. Cerita bermula dari seorang pria bernama Rio dan seorang temannya bernama Dahlan. Rio dan Dahlan adalah teman baik dari kecil. Akan tetapi mereka memiliki nasib yang sangat berbeda dalam hal pendidikan. Rio dan Dahlan sama-sama berasal dari keluarga sederhana di kampungnya. Rio selalu menyelesaikan sekolahnya dengan baik dan menyelesaikan pendidikannya sampai perguruan tinggi. Sedangkan Dahlan hanya menyelesaikan sekolahnya di bangku Sekolah Menengah Pertama (SMP). Setelah sekian lama tidak pulang ke kampungnya, akhirnya Rio memutuskan pulang dan tidak sengaja bertemu dengan teman lamanya Dahlan. Betapa sedihnya Rio setelah mengetahui dahlan sudah menikah dan punya anak. Akan 
tetapi satu pun anaknya tidak ada yang sekolah dikarenakan biaya yang tidak mencukupi. Dahlan berceria dulu setelah lulus SMP dia melamar pekerjaan di perusahan sawit dan menjadi mandor. Suatu hari perusahaan sawit mengalami defisit sehingga karyawan harus dikurangi. Pihak perusahaan memilih karyawan dengan pendidikan minimal SMA untuk tetap bekerja. Sedangkan karyawan dengan pendidikan dibawah SMA di PHK. Semenjak saat itu Dahlan tidak memiliki pekerjaan tetap. Sedangkan Rio sudah bekerja sebagai karyawan tetap disalah satu rumah sakit yang ada di ibu kota. Bahkan Rio dipercaya untuk memegang alat-alat penting di tempatnya bekerja dan sudah ditawari untuk melanjutkan sekolahnya ke jenjang lebih tinggi. Drama mini tersebut diperankan oleh siswa kelas IX. Pemilihan pemain sengaja memilih siswa kelas IX mengingat siswa siswi tersebut akan segera lulus dari SMP Negeri sungai Mali.

Sesi terakhir adalah evaluasi kegiatan berupa pemberian angket kepada seluruh peserta sosialisasi. Peserta yaitu siswa diminta untuk mengisi angket yang berisi pernyataan tentang pengetahuan yang telah diperoleh dari kegiatan sosialisasi dan motivasi untuk melanjutkan pendidikan setelah menyelesaikan sekolah di SMP Negeri Sungai Mali. Sedangkan orangtua diminta untuk mengisi angket tentang keinginan orangtua untuk mendukung anaknya dalam melanjutkan pendidikan ke jenjang yang lebih tinggi

\section{SIMPULAN}

Adapun kesimpulan dari kegiatan pengabdian masyarakat dengan tema "Sosialisasi Pentingnya Pendidikan Tinggi di SMP Negeri Sungai Mali adalah sebagai berikut:

a. Kehadiran dan tingkat partisipasi peserta meliputi seluruh siswa dan guru serta perangkat desa presensi kehadiran adalah 100 orang atau $90 \%$, beberapa siswa tidak dapat hadir dikarenakan sakit sedangkan beberapa perangkat desa berhalangan hadir karena alasan tertentu.

b. Pelaksanaan pengabdian sesuai dengan tanggal yang telah ditetapkan. Akan tetapi, mengalami sedikit kendala dikarenakan lokasi pengabdian kebanjiran sehingga waktu diundur.

c. Pelaksanaan pengabdian berjalan dengan lancar. Hal itu terlihat dari animo peserta yang antusias untuk mengikuti kegiatan penyuluhan sangat tinggi. Hal ini mengindikasikan bahwa para peserta menyambut positif kegiatan yang telah dilakukan

Pada akhir kegiatan, pihak sekolah dan perangkat desa berharap agar kegiatan pengabdian dapat 
dilaksanakan kembali tahun depan. Hal tersebut diungkapkan oleh kepala sekolah dan kepala desa kepada anggota pengabdian. Menurut para siswa sebagai peserta bahwa kegiatan ini sangat bermanfaat dalam memotivasi untuk melanjutkan pendidikan yang lebih tinggi

\section{DAFTAR RUJUKAN}

Dalyono. 2008. Psikologi

Pendidikan. Jakarta: Rineka Cipta.

Hasbullah. 2015. Dasar-Dasar Ilmu Pendidikan. Jakarta: Rajawali Pers.

Tirtahardja, Umar dan La. Sula. 2000. Pengantar Pendidikan. Jakarta: Rineka Cipta.

Undang-Undang No 20 tahun 2003 tentang Sistem Pendidikan Nasional

Ana Sudarwati Ardhie Raditya . 2014. Alasan Rasional Lulusan SMK Berkuliah. Jurnal Paradigma. Vol 2, No 1 (2014). http://jurnalmahasiswa.unesa. ac.id/index.php/paradigma/art icle/view/6979

Suryana. 2017. Permasalahan Mutu Pendidikan Dalam Perspektif Pembangunan Pendidikan. Jurnal Edukasi. Vol 2, No 1 (2017).

https://journal.unnes.ac.id/nju /index.php/edukasi/article/vie w/971
Siti Khadijah, Henny Indrawati. Suarman. 2017. Analisis Minat Peserta Didik untuk Melanjutkan Pendidikan Tinggi. JPIS Jurnal Pendidikan Ilmu Sosial Volume 26, Nomor 2, Desember 2017 e-ISSN 2540-7694 p-ISSN 08545251

http://ejournal.upi.edu/index. php/jpis 